\title{
Neuronal changes caused by Trypanosoma cruzi: an experimental model
}

\author{
NEIDE M. MOREIRA ${ }^{1}$, DÉBORA M.G. SANT'ANA ${ }^{2}$, EDUARDO J.A. ARAÚJO ${ }^{2}$, \\ MAX J.O. TOLEDO ${ }^{3}$, MÔNICA L. GOMES ${ }^{3}$ and SILVANA M. DE ARAÚJO ${ }^{3}$ \\ ${ }^{1}$ Programa de Pós-graduação em Ciências da Saúde, Universidade Estadual de Maringá, \\ Avenida Colombo, 5790, Zona 07, 08020-900 Maringá, PR, Brasil \\ ${ }^{2}$ Universidade Paranaense, Praça Mascarenhas de Moraes, 4282, Centro, 87502-210 Umuarama, PR, Brasil \\ ${ }^{3}$ Departamento de Ciências Básicas da Saúde - Parasitologia, Universidade Estadual de Maringá, \\ Avenida Colombo, 5790, Zona 07, 08020-900 Maringá, PR, Brasil
}

Manuscript received on June 26, 2010; accepted for publication on August 18, 2010

\begin{abstract}
Define an experimental model by evaluating quantitative and morphometric changes in myenteric neurons of the colon of mice infected with Trypanosoma cruzi. Twenty-eight Swiss male mice were distributed into groups: control $(\mathrm{CG}, \mathrm{n}=9)$ and inoculated with $100\left(\mathrm{IG}_{100}, \mathrm{n}=9\right)$ and $1000\left(\mathrm{IG}_{1000}, \mathrm{n}=10\right)$ blood trypomastigotes, Y strain-T. cruzi II. Parasitemia was evaluated from 3-25 days post inoculation (dpi) with parasites peak of $7.7 \times 10^{6}$ and $8.4 \times 10^{6}$ trypomastigotes $/ \mathrm{mL}$ at $8^{\text {th }}$ dpi $(\mathrm{p}>0.05)$ in $\mathrm{IG}_{100}$ and $\mathrm{IG}_{1000}$, respectively. Chronic phase of the infection was obtained with two doses of $100 \mathrm{mg} / \mathrm{Kg} /$ weight and one dose of $250 \mathrm{mg} / \mathrm{Kg} /$ weight of Benznidazole on 11,16 and 18 dpi. Three animals from each group were euthanized at 18, 30 and 75 dpi. The colon was stained with Giemsa. The quantitative and morphometric analysis of neurons revealed that the infection caused a decrease of neuronal density on $30^{\text {th }} \mathrm{dpi}(\mathrm{p}<0.05)$ and $75 \mathrm{dpi}(\mathrm{p}<0.05)$ in $\mathrm{IG}_{100}$ and $\mathrm{IG}_{1000}$. Infection caused death and neuronal hypertrophy in the $75^{\text {th }}$ dpi in $\mathrm{IG}_{100}$ and $\mathrm{IG}_{1000}(\mathrm{p}<0.05, \mathrm{p}<0.01)$. The changes observed in myenteric neurons were directly related to the inoculate and the time of infection.
\end{abstract}

Key words: Chagas disease, colon, enteric nervous system, Giemsa, Trypanosoma cruzi.

\section{INTRODUCTION}

Chagas disease is caused by Trypanosoma cruzi, affecting 8-9 million people in Latin America and the Caribbean (Hotez et al. 2008), having 50,000 new cases yearly (Senior 2007) and representing a huge socioeconomic problem. Multinational efforts conducted in the past 15 years have reduced by $50 \%$ the number of new cases in the Southern Cone and Central American countries (Jannin and Vila 2007, Senior 2007).

However, Marin-Neto et al. (2007) showed that 5.4 million people will develop the chronic Chagas disease, and 900,000 will develop megaesophagus and megacolon in the coming years (Pan American Health Organization - PAHO 2007). The manifestations in

Correspondence to: Neide Martins Moreira

E-mail: neidemartinsenf@yahoo.com.br/smaraujo@uem.br the digestive tube occur because of the non-uniform destruction of the neuronal cells in the Enteric Nervous System - ENS (Adad et al. 2001, Silveira et al. 2007a). The denervation of the myenteric plexus becomes evident in the Chagas disease and it is assumed to be the major causal factor of the malfunction of the mechanisms of motility and intestinal secretion observed in the chronic phase (Maifrino et al. 1999, 2005). Experimental infections indicated that neuronal denervation plays a crucial role in the changes of the gastrointestinal functions (Maifrino 1996, Maifrino et al. 1999, 2005).

Patients with such disorders need assistance with follow-up of the evolution of their conditions and proper therapy. In terms of trypanocidal drugs, the benznidazole and/or nifurtimox have a protective effect in the clinical evolution, even though they are not fully 
effective with respect to the total elimination of the parasite (Fabbro et al. 2007). Therefore, even patients undergoing etiologic treatment can present symptoms of constipation and other severe intestinal complications (Santos and Monteiro 2002) which, turns the study of alternative ways to prevent the assisted ones from having extreme symptoms into a big challenge.

The Laboratório de Doença de Chagas da Universidade Estadual de Maringá (LDCh/UEM) has the purpose of improving the assistance to patients infected with T. cruzi (Araújo et al. 2000). It has been investing on basic and applied researching, as well as evaluating classic and alternative interventions (Aleixo et al. 2008, D'Arce Mota et al. 2008, Schebeleski-Soares et al. 2009). Experimental models are necessary for the conduction of basic research. Myenteric denervation has already been reported for murine models (Maifrino et al. 1999, 2005) and can be used as an effective marker for therapeutic interventions. However, it is necessary to evaluate the occurrence of such disorders and their properties concerning the conditions of each research laboratory.

The T. cruzi Y strain is polyclonal and largely used in experimental studies. It is composed of a number of subpopulations of the parasite and has been recently classified as belonging to the T. cruzi II genetic lineage (Araújo and Chiari 1988, Murta and Romanha 1998, Martins et al. 2008). Some factors, such as culture media and the schedule of in vitro maintenance, lineages and age of the experimental mice used, inocula, passages by the vector and in vitro maintenance, can favor the predominance of certain subpopulations, thus changing the behavioral standard of the original strain.

This study had the purpose of establishing an experimental model approaching the quantitative and morphometric changes in the myenteric neurons of the colon of mice infected with the strain Y of T. cruzi II in the LDCh/UEM, Paraná, Brazil.

\section{MATERIALS AND METHODS}

\section{ETHICAL Aspects}

This study was approved by the Comitê de Conduta Ética no uso de Animais em Experimentação (CEAE) of the UEM (Protocol 046/2009), and complies with the ethical principles involving animal experimentation adopted by Sociedade Brasileira de Ciência em Animais de Laboratório (SBCAL).

\section{ANIMALS AND INFECTION}

Twenty-eight Swiss male mice, Mus musculus, 60 days of age, $38.26 \pm 4.27 \mathrm{~g}$, were divided into 3 groups: Control Group (CG, n=9), Group Inoculated with $100\left(\mathrm{IG}_{100}\right.$, $\mathrm{n}=9)$ (via i.p.) and 1,000 ( $\left.\mathrm{IG}_{1000}, \mathrm{n}=10\right)$ (via i.p.) blood trypomastigotes from the strain $\mathrm{Y}$ of $T$. cruzi.

The animals were housed in polypropylene rodent cages $(414 \times 344 \times 168 \mathrm{~mm})$ and allocated in a temperature-controlled vivarium $\left(21-23^{\circ} \mathrm{C}\right)$ with a $12 \mathrm{~h}$ dark/light cycle. They received water (chlorinated) and a commercial rodent diet (Nuvilab Cr-1 ${ }^{\circledR}$, Nuvital $\left.{ }^{\circledR}\right)$ ad libitum.

\section{ASSESSEMENT OF THE EVOLUTION OF THE INFECTION}

Parasitemia was evaluated by using Brener's technique (1962). The counting of the parasites was conducted daily, from 3 to 13 days post inoculation (dpi) and on alternate days from 14 to $25 \mathrm{dpi}$. The parasitemia curve was obtained by using the average parasitemia in each group. The following parameters were evaluated:

- Infectivity;

- Prepatent period: average time, in days, between inoculation and the day positivity in the fresh blood examination for each group;

- Patent period: average time, in days, in each group showed parasitemia detected in the fresh examination;

- Peak of parasites: represented by the highest number of parasites observed in each group from the curve of average parasitemia;

- Total parasitemia: average of the sum of the parasitemia of each day in each group;

- Cumulative mortality: registered throughout the whole experiment -75 days;

- Weight of the animals: verified in the beginning of the experiment, at 18, 30, and 75 dpi.

\section{INDUCTION OF THE CHRONIC PHASE}

The induction of the chronic phase was obtained by administering two doses of $100 \mathrm{mg} / \mathrm{kg} /$ weight and one dose of $250 \mathrm{mg} / \mathrm{kg} /$ weight of Benznidazole at 11,16 , and 18 dpi, respectively. 


\section{EUthanAsia of ANIMALS AND COLLECTION OF ORGANS}

At 18, 30, and 75 dpi, 3 animals from each group were euthanized by an overdose of Ether inhalation. After vertical laparotomy, they had their colon removed and washed in a $0.85 \%$ saline solution, filled and fixed in formalin-acetic acid solution for $48 \mathrm{~h}$, dissected, and the whole mounts of the serosa and the muscle tunic were stained with Giemsa (Barbosa 1978). The measuring of width and length of the organ was conducted on the colons removed at 75 dpi to calculate its area.

\section{QuAntitative ANALYsis}

At 18, 30, and $75 \mathrm{dpi}$, the myenteric neurons in 120 microscopic fields equitably distributed all over the intestinal circumference of the proximal, middle and distal segments in the colon of each mice were quantified, totalizing 360 fields examined. A photonic microscope (Olympus CBA) with a $40 \times$ objective was used. The denervation (neuronal death) was evaluated by comparing the infected and control groups and expressed as a percentage. As there was no statistic differences among the population density of the neurons in the three segments of the colon evaluated in the same group, the data are presented as the total density of the neuronal population (proximal + middle + distal colons) for the comparisons amongst the groups.

\section{MORPHOMETRIC ANALYSIS}

The area of the body cell and nucleus of 300 neurons of the myenteric plexus equitably distributed all over the intestinal circumference of the colon of the animals at 75 dpi was measured. The images were captured by using a trinocular microscope (Motic B5) attached to a high definition digital camera (MOTICAM 2000). The area of the cytoplasm - the difference between the area of the body cell and the area of the nucleus (1) and the ratio between the area of the nucleus and the area of the body cell (2) - was calculated. The neurons were distributed into class intervals of area of cell body, and the ratio among the areas of the body cell, nucleus and cytoplasm was established. It was performed a correlation analysis among the areas of the cell body, nucleus and cytoplasm.

\section{Statistical Analysis}

Data with normal distribution were expressed as mean \pm standard deviation. Data with non-specified distribution were expressed as median and percentiles 25 and 75 (P25 and P75), respectively. The ANOVA-Tukey tests (data with normal distribution), Kruskall-Wallis and test of Medians (data with non-specific distribution), with a significance level of $5 \%$, were used for the comparison of the data among the groups. BioEstat 5.0 ${ }^{\circledR}$ was used.

\section{RESULTS}

\section{EVOLUTION OF THE INFECTION}

The curve of parasitemia presented the characteristic profile of the strain $\mathrm{Y}$ with a peak of $7.72 \times 10^{6}$ and $8.47 \times 10^{6}$ trypomastigotes $/ \mathrm{mL}$ at $8 \mathrm{dpi}$ in the animals from $\mathrm{IG}_{100}$ and $\mathrm{IG}_{1000}$. Likewise, there was no statistic differences amongst infectivity, prepatent period, patent period and total parasitemia in the groups evaluated (Fig. 1, Table I). The body weight of the animals did not vary significantly amongst the groups from the beginning of the experiment to 18,30 and $75 \mathrm{dpi}$ (Table II).

At $75 \mathrm{dpi}$, the colon of the mice infected with 100 and 1,000 blood trypomastigotes presented $9.3 \mathrm{~cm}$ and $10.0 \mathrm{~cm}$ length $(\mathrm{p}=0.0591)$ and $1.2 \mathrm{~cm}$ and $1.5 \mathrm{~cm}$ width $(p>0.05)$, respectively. Therefore, the total area of the organ was larger in the proportion of $32.74 \%$ in $\mathrm{IG}_{1000}$, when compared to the $\mathrm{CG}$, without presenting statistic differences $(\mathrm{p}>0.05)$ (Table III and Figure 2).

\section{Quantitative Analysis of the Myenteric Plexus}

In Table IV, the neuronal density of the CG was observed to have remained constant throughout time $(p>0.05)$, whereas in the IG this parameter decreased significantly $(\mathrm{p}<0.05)$. At $18 \mathrm{dpi}$, a decrease of $0 \%$ in the neuronal density in the $\mathrm{IG}_{100}$ and $9 \%$ in the $\mathrm{IG}_{1000}$ in relation to the CG was observed - without statistic differences $(p>0.05)$. At $30 \mathrm{dpi}$, the animals from the $\mathrm{IG}_{100}$ and $\mathrm{IG}_{1000}$ presented a decrease of the neuronal density of $28.1 \%$ and $35.1 \%$, respectively, in relation to the $\mathrm{CG}(\mathrm{p}<0.05)$. At $75 \mathrm{dpi}$, a decrease of $52.0 \%$ in the $\mathrm{IG}_{100}$ and $57.0 \%$ in the $\mathrm{IG}_{100}$ was observed in relation to the $C G(p<0.05)$. When the projection of the number of neurons in the total area of the colon was evaluated, the neuronal death of $59.0 \%$ in the $\mathrm{IG}_{100}$ and 


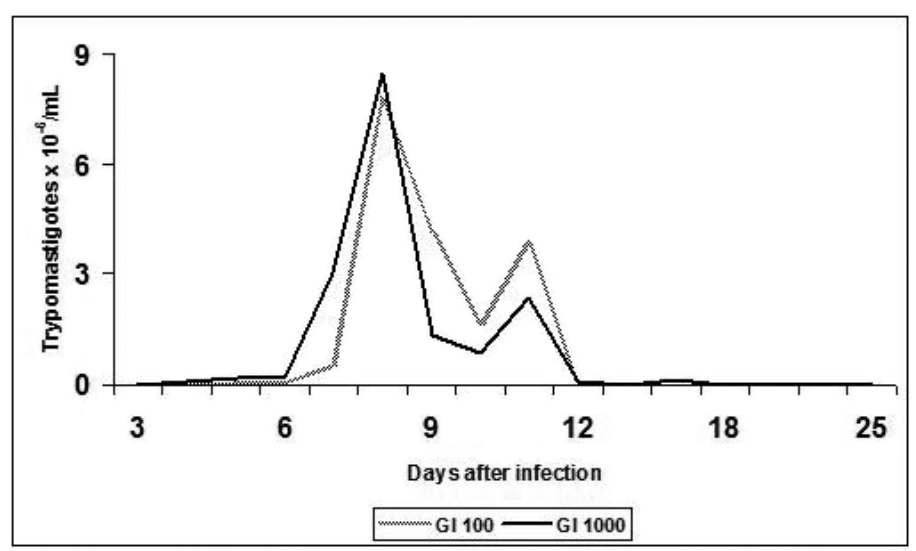

Fig. 1 - Curve of average parasitemia in 60-day-old Swiss male mice infected by the strain $\mathrm{Y}$ of $T$. cruzi. $\mathrm{IG}_{100}$ - animals inoculated with 100 blood trypomastigotes, $\mathrm{IG}_{1000}$ - animals inoculated with 1000 forms of blood trypomastigotes.

TABLE I

Parasitological parameters evaluated in 60-day-old Swiss male mice experimentally infected by $T$. cruzi Y strain.

\begin{tabular}{c|c|c|c|c|c}
\hline Group & $\begin{array}{c}\text { Infectivity } \\
(\%)\end{array}$ & $\begin{array}{c}\text { Prepatent period } \\
\text { (days) }\end{array}$ & $\begin{array}{c}\text { Patent period } \\
\text { (days) }\end{array}$ & $\begin{array}{c}\text { Peak of parasites } \\
\left.\text { (trypomastigotes } / \mathrm{mL} \times 10^{6}\right)\end{array}$ & $\begin{array}{c}\text { Total parasitemia } \\
\left.\text { (trypomastigotes } / \mathrm{mL} \times 10^{6}\right)\end{array}$ \\
\hline $\mathrm{IG}_{100}$ & 100 & $4.89 \pm 0.93$ & $12.67 \pm 1.94$ & $7.72 \pm 2.96$ & $18.23 \pm 6.70$ \\
\hline $\mathrm{IG}_{1000}$ & 100 & $4.00 \pm 0.00$ & $12.20 \pm 2.39$ & $8.67 \pm 7.74$ & $16.78 \pm 6.17$ \\
\hline
\end{tabular}

$\mathrm{IG}_{100}, \mathrm{IG}_{1000}$ - animals inoculated with 100 or 1000 blood trypomastigotes.

TABLE II

Average body weight of Swiss male mice infected with $100\left(\mathrm{IG}_{100}\right)$ and $1000\left(\mathrm{IG}_{1000}\right)$ forms of blood trypomastigotes from $T$. cruzi $\mathrm{Y}$ strain and the non-infected controls (Control Group - CG).

\begin{tabular}{c|c|c|c|c}
\hline \multirow{2}{*}{ Groups } & \multicolumn{4}{|c}{ Weight $(\mathrm{g})$} \\
\cline { 2 - 5 } & $\mathrm{T}_{0}(\mathrm{n}=28)$ & $\mathrm{T}_{18}(\mathrm{n}=28)$ & $\mathrm{T}_{30}(\mathrm{n}=19)$ & $\mathrm{T}_{75}(\mathrm{n}=10)$ \\
\hline $\mathrm{CG}$ & $40.16 \pm 3.96$ & $44.27 \pm 4.09$ & $45.72 \pm 6.30$ & $37.03 \pm 26.73$ \\
\hline $\mathrm{IG}_{100}$ & $37.22 \pm 4.32$ & $41.06 \pm 4.15$ & $45.24 \pm 5.36$ & $36.32 \pm 27.09$ \\
\hline $\mathrm{IG}_{1000}$ & $37.49 \pm 4.35$ & $39.69 \pm 4.96$ & $44.70 \pm 4.18$ & $40.17 \pm 24.11$ \\
\hline
\end{tabular}

$\mathrm{T}_{0}=$ beginning of the experiment, $\mathrm{T}_{18,30}$ and $75=18,30$ and $75 \mathrm{dpi}$-days post inoculation. Values expressed as mean \pm standard deviation. There was no statistic difference among the values observed in the different groups at the times evaluated.

$63.4 \%$ in the $\mathrm{IG}_{1000}(\mathrm{p}<0.05)$ was verified. Statistic differences in the same group were observed on different days of infection. At 18 and 75 dpi, there was a significant difference $(\mathrm{p}<0.01)$ for both $\mathrm{IG}_{100}$ and $\mathrm{IG}_{1000}$.

\section{Morphometry OF THE MYENTERIC NEURONS}

The values for the area of the cell body, area of the nucleus, area of the cytoplasm and nucleus/body cell ratio for the groups studied are presented in Table V.
Hypertrophy was observed in all parameters evaluated, except for the nucleus/body cell ratio, as follows. The increase of $\left.154.0 \% 55.9 \mu \mathrm{m}^{2}\right)$ and $176.0 \%\left(60.7 \mu \mathrm{m}^{2}\right)$ in the area of the nucleus in the $\mathrm{IG}_{100}$ and $\mathrm{IG}_{1000}$, respectively, was observed when compared to the CG $\left(22.0 \mu \mathrm{m}^{2}\right)(\mathrm{p}<0.05)$. The area of the cytoplasm presented an increase of $181.0 \%\left(95.8 \mu \mathrm{m}^{2}\right)$ and $199.0 \%$ $\left(101.8 \mu \mathrm{m}^{2}\right)$ in the $\mathrm{IG}_{100}$ and $\mathrm{IG}_{1000}$, respectively, in relation to the $\mathrm{CG}\left(34.1 \mu \mathrm{m}^{2}\right)(\mathrm{p}<0.05)$. It could 
TABLE III

Mean and standard deviation in length, width and area of the colon of $S$ wiss male mice infected by the strain Y of $T$. cruzi

$\left(\mathrm{IG}_{100}\right.$ and $\left.\mathrm{IG}_{1000}\right)$ at $75 \mathrm{dpi}$ - days post inoculation and the non-infected controls (CG).

\begin{tabular}{c|c|c|c}
\hline Groups & Length $(\mathrm{cm})$ & Width $(\mathrm{cm})$ & Area $\left(\mathrm{cm}^{2}\right)$ \\
\hline $\mathrm{CG}$ & $9.0 \pm 2.3$ & $1.2 \pm 0.1$ & $11.3 \pm 4.1$ \\
\hline $\mathrm{IG}_{100}$ & $9.3 \pm 2.0$ & $1.2 \pm 0.2$ & $11.1 \pm 2.0$ \\
\hline $\mathrm{IG}_{1000}$ & $10.0 \pm 1.1$ & $1.5 \pm 0.1$ & $15.0 \pm 2.3$ \\
\hline
\end{tabular}

Values expressed as mean \pm standard deviation. There was no statistic difference among the values observed in the different groups at the times evaluated. $\mathrm{IG}_{100}, \mathrm{IG}_{1000}$ - animals inoculated with 100 or 1000 blood trypomastigotes.

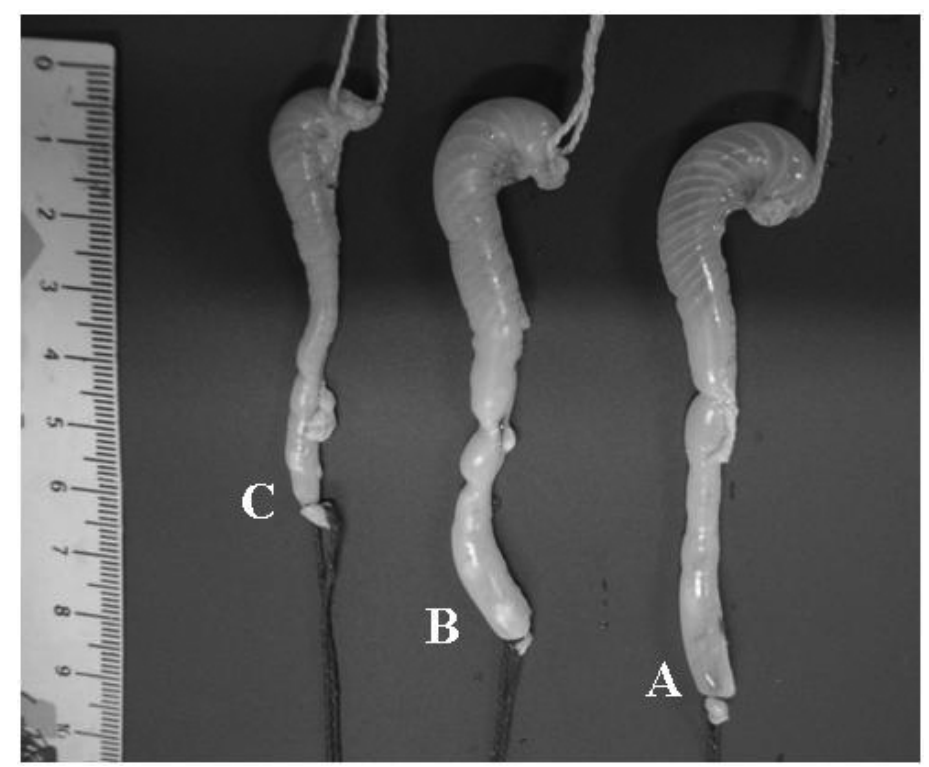

Fig. 2 - Colon of Swiss male mice inoculated with 1000 (A) and 100 (B) blood trypomastigotes from the strain $\mathrm{Y}$ of $T$. cruzi at $75 \mathrm{dpi}$ - days post inoculation and the non-infected controls (C).

also be observed that the area of the cell body increased $173.0 \%\left(153.5 \mu \mathrm{m}^{2}\right)$ in the $\mathrm{IG}_{100}$ and $198.0 \%$ $\left(167.5 \mu \mathrm{m}^{2}\right)$ in the $\mathrm{IG}_{1000}$, in relation to the $\mathrm{CG}$ $\left(56.2 \mu \mathrm{m}^{2}\right)(\mathrm{p}<0.0001)$. A significant increase of the area of the body cell, cytoplasm and nucleus was also observed in the animals in the $\mathrm{IG}_{100}$ and $\mathrm{IG}_{1000}$. The ratio for the area of the nucleus and the area of the body of the myenteric neurons in the animals in the $\mathrm{IG}_{100}$ and $\mathrm{IG}_{1000}$ presented a significant decrease $(\mathrm{p}<$ 0.05 ) in relation to the $\mathrm{CG}$; however, no statistic differences were observed when comparing the IGs.

The degree of correlation among the area of the body, nucleus and cytoplasm of the neurons measured is presented in Table VI.
Statistic differences among the $\mathrm{CG}, \mathrm{GI}_{100}$ and $\mathrm{GI}_{1000}$ for the classes of neurons according to the area of the body cell in intervals of $<50 \mu \mathrm{m}^{2} ; 51-100 \mu \mathrm{m}^{2}$; $101-150 \mu \mathrm{m}^{2} ; 151-200 \mu \mathrm{m}^{2}$ and $>201 \mu \mathrm{m}^{2} \quad(\mathrm{p}<0.01)$ and between $\mathrm{GI}_{100}$ and $\mathrm{GI}_{1000}$ in the class $101-150 \mu \mathrm{m}^{2}$ $(\mathrm{p}<0.0001)$ are presented in Figure 3.

Statistic differences among the $\mathrm{CG}$ and $\mathrm{GI}_{100}$ for the class of neurons with nucleus/body ratio $0.21-30 \mu \mathrm{m}^{2}$ $(\mathrm{p}<0.05)$ are presented in Figure 4.

\section{DISCUSSION}

Most of the individuals infected with $T$. cruzi is currently in the chronic phase of the infection, lost alongside the Health System, without any perspective of 
TABLE IV

Mean and standard deviation of the myenteric neuronal density* in the colon of Swiss male mice infected by the strain $\mathrm{Y}$ with $100\left(\mathrm{IG}_{100}\right)$ and $1000\left(\mathrm{IG}_{1000}\right)$ forms of trypomastigotes and the non-infected controls.

\begin{tabular}{c|c|c|c|c}
\hline Group & 18 dpi $68.4 \mathrm{~mm}^{2}$ & 30 dpi $68.4 \mathrm{~mm}^{2}$ & $75 \mathrm{dpi} 68.4 \mathrm{~mm}^{2}$ & $\begin{array}{c}\text { Number of neurons in the total } \\
\text { area of the colon }(75 \text { days of the } \\
\left.\text { experiment } \times 10^{8}\right)\end{array}$ \\
\hline Control & $15.40 \pm 2.27$ & $14.83 \pm 2.19^{\mathrm{a}}$ & $16.09 \pm 4.96^{\mathrm{a}}$ & $31.85 \pm 11.96^{\mathrm{a}}$ \\
\hline $\mathrm{IG}_{100}$ & $18.95 \pm 5.01$ & $10.66 \pm 1.53^{\mathrm{b}}$ & $7.71 \pm 658^{\mathrm{c}}$ & $13.20 \pm 1.84^{\mathrm{d}}$ \\
\hline $\mathrm{IG}_{1000}$ & $14.04 \pm 1.95$ & $10.35 \pm 2.31^{\mathrm{b}}$ & $6.92 \pm 925^{\mathrm{c}}$ & $11.83 \pm 2.84^{\mathrm{d}}$ \\
\hline
\end{tabular}

*In 360 microscopic fields and area of $68.4 \mathrm{~mm}^{2}$. Data in the same column with different letters present significant differences $(\mathrm{a} \times \mathrm{b}: \mathrm{p}<0.05$; $\mathrm{a} \times \mathrm{c}: \mathrm{p}<0.01 ; \mathrm{a} \times \mathrm{d}: \mathrm{p}<0.05)$ dpi - days post inoculation.

TABLE V

Median of the area of the nucleus, cytoplasm and body cell of the myenteric neurons in the colon of $S$ wiss male mice infected by $T$. cruzi $Y$ strain with $100\left(\mathrm{IG}_{100}\right)$ and $1000\left(\mathrm{IG}_{1000}\right)$ forms of trypomastigotes and the non-infected controls.

\begin{tabular}{c|c|c|c}
\hline \multirow{2}{*}{ Parameter } & \multicolumn{3}{|c}{ Median (percentile 25; 75) } \\
\cline { 2 - 4 } & $\mathrm{CG}$ & $\mathrm{IG}_{100}$ & $\mathrm{IG}_{1000}$ \\
\hline Area of the Nucleus $\left(\mu \mathrm{m}^{2}\right)$ & $22.0^{\mathrm{a}}(15.2 ; 32.8)$ & $55.9^{\mathrm{b}}(42.0 ; 70.8)$ & $60.7^{\mathrm{c}}(46.3 ; 79.7)$ \\
\hline Area of the Cytoplasm $\left(\mu \mathrm{m}^{2}\right)$ & $34.1^{\mathrm{a}}(21.0 ; 57.4)$ & $95.8^{\mathrm{b}}(63.6 ; 147.7)$ & $101.8^{\mathrm{c}}(65.4 ; 161.4)$ \\
\hline Area of the Body Cell $\left(\mu \mathrm{m}^{2}\right)$ & $56.2^{\mathrm{a}}(38.1 ; 89.8)$ & $153.5^{\mathrm{b}}(112.8 ; 213.0)$ & $167.5^{\mathrm{c}}(119.8 ; 234.1)$ \\
\hline Nucleus/Body Cell ratio & $0.38^{\mathrm{a}}(0.30 ; 0.47)$ & $0.37^{\mathrm{b}}(0.28 ; 0.44)$ & $0.37^{\mathrm{b}}(0.28 ; 0.46)$ \\
\hline
\end{tabular}

Values followed by different letters in the same line express statistically significant differences $(p<0.05)$.

TABLE VI

Correlation index among the area of the nucleus, cytoplasm and body cell in the myenteric neurons of the colon of $S$ wiss male mice infected by $100\left(\mathrm{IG}_{100}\right)$ and $1,000\left(\mathrm{IG}_{1000}\right)$ trypomastigotes forms of $T$. cruzi $Y$ strain and the non-infected controls.

\begin{tabular}{c|c|c|c}
\hline \multirow{2}{*}{$\begin{array}{c}\text { Relation between the } \\
\text { considered areas }\end{array}$} & \multicolumn{3}{|c}{ Correlation index } \\
\cline { 2 - 4 } & $\mathrm{CG}$ & $\mathrm{IG}_{100}$ & $\mathrm{IG}_{1000}$ \\
\hline Body cell $\times$ Nucleus & 0.84 & 0.68 & 0.70 \\
\hline Body cell $\times$ Cytoplasm & 0.95 & 0.96 & 0.95 \\
\hline Nucleus $\times$ Cytoplasm & 0.66 & 0.48 & 0.50 \\
\hline
\end{tabular}

treatment (Jurberg 2009). Some of the major complications of the Chagas disease are related to the compromising of the functioning of the digestive tube and heart. Among them, megacolon stands out as a result of the destruction of the enteric neurons (Silveira et al. 2008). These neurons are located in the wall of the colon, organized in ganglions and interconnected by bundles of nerve fibers that constitute the myenteric and sub- mucosal plexus (Furness and Costa 2006). Experimental models that are capable of reproducing the changes observed in the Chagas disease and enable the evaluation of interventions are necessary and important.

This paper had the purpose of establishing an experimental model of the chronic infection by $T$. cruzi by emphasizing the quantitative and morphometric changes in the myenteric neurons of the colon of mice in search 
for innovative approaches for therapeutic interventions in infected individuals.

The parasitological parameters evaluated in the strain $\mathrm{Y}$ showed high parasitemia according to the characteristics of such strain described in the literature (Brener 1962). Likewise, in a recent study, SchebeleskiSoares et al. (2009) showed the same behavior of the strain $\mathrm{Y}$ in $\mathrm{BALB} / \mathrm{c}$ female mice, but with mortality for all the infected animals. In this study, the chronification of the infection with low mortality was due to the discontinuous treatment with benznidazole. The use of two different inocula, despite of not reflecting the differentiation of parasitological parameters, caused differences in the morphometry of the myenteric neurons.

According to the literature, the infection by $T$. cruzi causes progressive weight loss and even cachexy in humans (Meyer et al. 2006). In this study, the body weight of the animals was not significantly different amongst the infected and control groups at 18, 30, 75 dpi. This was probably due to the treatment conducted with benznidazole for the chronification of the infection. Although this drug did not present full efficacy in terms of cure, it restrains the evolution of the parasitemia, which is, at last, one of the causes of morbidity of the infection by T. cruzi (Fabbro et al. 2007).

Regarding the number of neurons amongst the different segments of the colon (proximal, middle and distal), no differences were observed for the mice inoculated with 100 and 1,000 blood trypomastigotes and the control group. These data are in accordance with those of Maifrino (1996), who also observed no significant difference, in the number of neurons among the three segments of the colon of mice at 50 days of infection with 1,000 blood form of the strain Y of T. cruzi and its controls.

At $75 \mathrm{dpi}$, the increase of $0 \%$ and $25 \%$ in the width of the colon in the $\mathrm{IG}_{100}$ and $\mathrm{IG}_{1000}$, respectively, was observed in relation to the non-infected group. The increase of $3.3 \%\left(\mathrm{IG}_{100}\right)$ and $11.1 \%\left(\mathrm{IG}_{1000}\right)$ in length was verified in relation to the CG. Thus, the infection was observed to cause a tendency to the hypertrophy of the colon and, consequently, the total area of the organ with $0.0 \% \mathrm{IG}_{100}$ and $32.7 \% \mathrm{IG}_{1000}$, when compared to the $\mathrm{CG}$, although presenting no statistic differences $(p>0.05)$. Neither macroscopic changes nor fecal im- paction were observed. In studies conducted with patients with Chagas disease, the neuronal decrease was observed related to the megacolon (Adad et al. 2001, Iantorno et al. 2007, Silveira et al. 2007a, 2008). In this study, the decrease of the neuronal population was not related to the change in width and height of the organ. This certainly can be related to other factors such as the parasite-host relation, the inoculum and, mainly, the time of infection to which the animals were submitted.

Several studies had already showed that the destruction of the myenteric neurons triggers an important change of motility in the colon causing megacolon (Koberle 1968, 1970, Tafuri et al. 1971, Maifrino et al. 1999, 2005, Iantorno et al. 2007, Silveira et al. 2007a, b, 2008) - a phenomenon dependent on the degree of parasitism and time of infection.

The animals in the $\mathrm{IG}_{100}$ and $\mathrm{IG}_{1000}$ had significant lower density of myenteric neurons than the animals in the CG. The data showed a tendency to denervation what was dependent on the time of infection. At $18 \mathrm{dpi}$, no difference was verified among the neuronal density of the colon of the mice in the three groups. These data differ from those of Arantes et al. (2004) who observed neuronal decrease of $60 \%$ at 10 dpi in the colon of C57BL/6 mice inoculated with 100 blood trypomastigotes of the strain Y, highlighting the importance of the genetic characteristics of the host in the determination of morbidity in the infection by $T$. cruzi. Although C57BL/6 mice are more resistant than Swiss mice, the high variation on genetic background in nonisogenic models may be responsible for the high degree of intrinsic variation and conclusions must be regarded with caution.

In this experiment, at $30 \mathrm{dpi}$, the decrease of neuronal density was $28.1 \%$ and $35.1 \%$ with the inocula of 100 and 1,000 forms of trypomastigotes, respectively. At $75 \mathrm{dpi}$, the decrease was $52.0 \% \mathrm{IG}_{100}$ and $57.0 \%$ $\mathrm{IG}_{1000}(\mathrm{p}<0.01)$ compared to control. These data agree with those of other researchers (Maifrino 1996, Maifrino et al. 1999, 2005) who observed neuronal decrease from $39.0 \%$ to $85.7 \%$ in the colon of mice infected with 100 and 1,000 forms of blood trypomastigotes of the strain $\mathrm{Y}$, validating our findings for the establishment of a model of denervation of the chronic infection by $T$. cruzi in mice. 


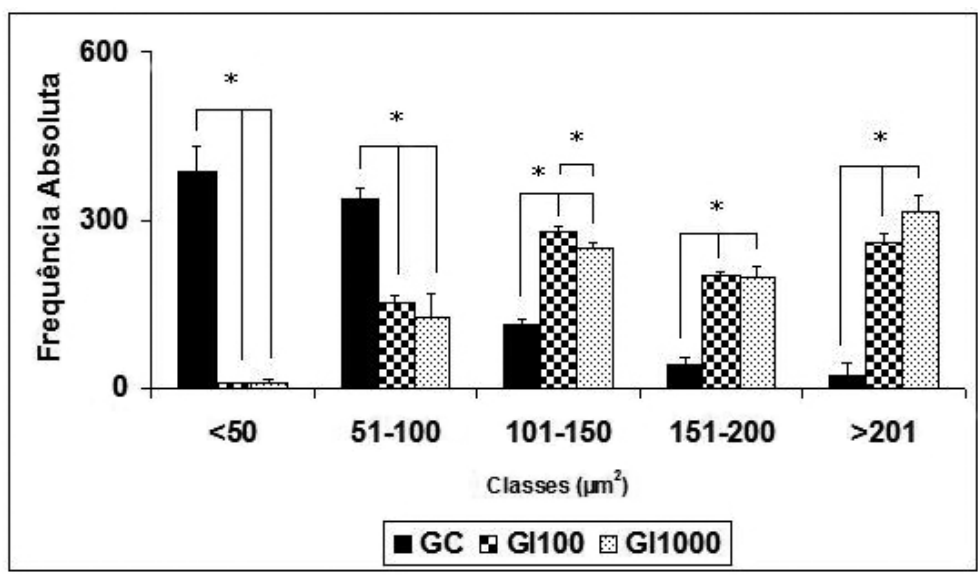

Fig. 3 - Histogram of the classes of myenteric neurons in the colon of Swiss male mice according to the area $\left(\mu \mathrm{m}^{2}\right)$ of the body cell in the animals inoculated with $100\left(\mathrm{IG}_{100}\right)$ and $1000\left(\mathrm{IG}_{1000}\right)$ trypomastigotes of $T$. cruzi $\mathrm{Y}$ strain at $75 \mathrm{dpi}$ - days post inoculation and the non-infected controls $(\mathrm{CG}) .\left({ }^{*}\right)=(\mathrm{P}<0.0001)$.

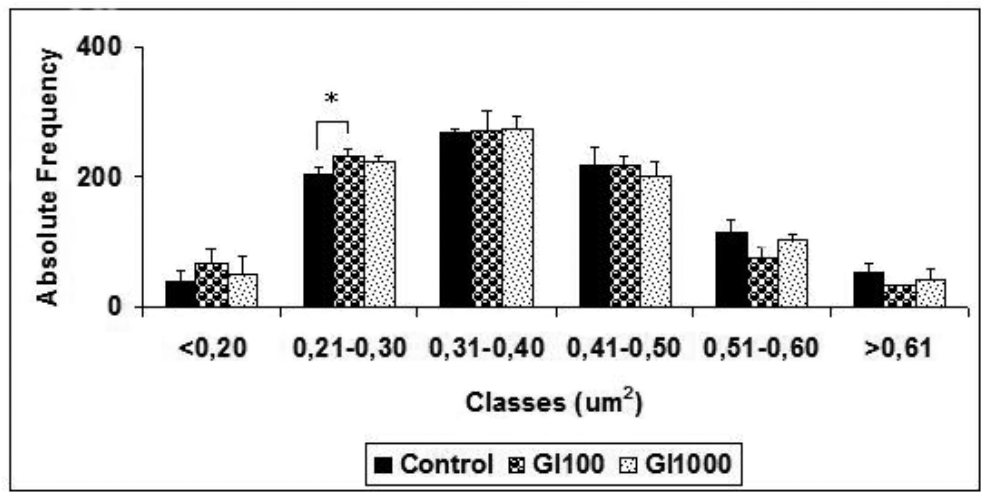

Fig. 4 - Histogram of the nucleus/body cell ratio in the myenteric neurons in the colon of Swiss male mice inoculated with $100\left(\mathrm{IG}_{100}\right)$ and $1,000\left(\mathrm{IG}_{1000}\right)$ trypomastigotes of $T$. cruzi Y strain at $75 \mathrm{dpi}$ - days post inoculation and the non-infected controls $(\mathrm{CG})\left(^{*}\right)=(\mathrm{p}<0.05)$.

Different authors showed that the colon of humans with Chagas disease presents a neuronal decrease from $55.0 \%$ to $66.67 \%$ (Adad et al. 2001, Silveira et al. 2007a, 2008). The differences in the percentages obtained by different researchers are probably due to different neuronal classes investigated, strain of the parasite, inoculum and time of infection.

At $75 \mathrm{dpi}$, the projection of the number of neurons for the total area of the colon was evaluated. A neuronal death index of $59.0 \%$ in the $\mathrm{IG}_{100}$ and $63.4 \%$ in the $\mathrm{IG}_{1000}(\mathrm{p}<0.05)$ was verified when compared to the CG. It was possible to notice that such evaluation was not conducted in former studies (Maifrino 1996, Maifrino et al. 1999, 2005). Statistic differences $(\mathrm{p}<0.01)$ were observed within the same experimental group from 18 to 75 days of infection in both $\mathrm{IG}_{100}$ and $\mathrm{IG}_{1000}$.

The data showed hypertrophy of the myenteric neurons in the animals in the $\mathrm{IG}_{100}$ and $\mathrm{IG}_{1000}$ as the nucleus increased $154.0 \%\left(\mathrm{IG}_{100}\right)$ and $176.0 \%\left(\mathrm{IG}_{1000}\right)$. The cytoplasm increased $181.0 \%$ and $199.0 \%$ and, consequently, the cell body increased significantly $(\mathrm{p}<$ $0.0001) 173.0 \%$ and $198.0 \%$, respectively, in $\mathrm{IG}_{100}$ and $\mathrm{IG}_{1000}$. The increase of the body cell suggested to have been caused mainly by the increase of the cytoplasm as the degree of correlation among these parameters, is high despite the size of the inoculum (100: $\mathrm{r}=0.96$ / $\mathrm{p}<0.0001$ and 1.000: $\mathrm{r}=0.95 / \mathrm{p}<0.0001)$. It also suggested that the decrease of the degree of correlation be- 
tween the cytoplasm and the nucleus of the neurons in the animals in $\mathrm{IG}_{100}(\mathrm{r}=0.48$ and $\mathrm{p}<0.0001)$ and $\mathrm{IG}_{1000}(\mathrm{r}=0.50$ and $\mathrm{p}<0.0001)$ has contributed for the decrease of the area of the nucleus/cell body ratio in the IGs, indicating that the cytoplasm began to occupy more space in the cell. The neuronal hypertrophy observed in the animals in $\mathrm{IG}_{100}$ and $\mathrm{IG}_{1000}$ explains the progressive increase of the number of neurons when distributed in classes according to the area of the cell body. The inversely proportional distribution for this number of neurons when comparing the CG to the IGs stands out, and the class marking this inversion was the one with neurons with a median from 101 to $150 \mu \mathrm{m}^{2}$. Although a discrete decrease of the area of the nucleus/ area of the cell body ratio was observed, considering the infected and control groups, practically no change was observed in the distribution of the number of neurons in the intervals of class regarding this parameter, showing that this phenomenon occurred homogeneously among the neurons in the colon. Maifrino et al. (1999), while studying specific subpopulations of neurons (NADH-d and $\mathrm{AChE}$ ) in the colon of Swiss male mice infected with 1,000 forms of trypomastigotes of the strain Y of T. cruzi for 60 days, observed a significant death of medium and large neurons. Nevertheless, while using the inoculum with 100 forms of trypomastigotes of the same strain and time of infection, no significant morphometric change was observed in the neurons stained with NADH-d in the colon of BALB/c male mice (Maifrino et al. 2005).

This morphometric analysis of the myenteric neurons enabled to sustain the hypothesis that the physiology of the myenteric neurons is changed when the host is parasited by $T$. cruzi. The hypertrophy of the survival neuronal population was observed in the infected animals. Besides, in these animals, the neurons also had their nuclei increased, presenting a significant change between $\mathrm{IG}_{100}$ and $\mathrm{IG}_{1000}$, and this relation demonstrated to be proportionally different the inoculum. This finding suggests that there was an increase of the gene expression for a higher production of proteins with consequent increase of the cytoplasm. Chagas disease is characterized by the development of generalized inflammatory process (De Lana and Tafuri apud Neves et al. 2005). Silveira et al. (2007b) observed, in the myen- teric plexus in the colon of patients with Chagas disease with megacolon, that the excitatory neurons that produce substance $P$ had an increase in the frequency of neurochemical markers. Substance P, while secreted, contributes for the neurogenesis of the inflammation (Winter et al. 1995). Likewise, Silveira et al. (2008) found high levels of substance $P$ while studying the expression of this neuropeptide in patients with chagasic megacolon. In this study, hypertrophy in the neurons is suggested to be related to the neurochemical marker. Future studies involving the analysis of neurotransmitters and neuromodulators are necessary to understand the mechanism of action of the parasite in the myenteric denervation, considering the proposed model.

Considering that the Laboratório de Doença de Chagas/UEM has the purpose of improving the attention provided to the subject infected by $T$. cruzi, even when basic research is conducted, we sought in this study a direct relation between the findings and their practical application. Literature shows that capsaicin (an active component of black pepper) stimulates the release of substance $\mathrm{P}$; however, the continuous use of capsaicin leads to the depletion of the substance $P$ involved in the inflammatory process (Graton 2009, Winter et al. 1995). Therefore, we have evidences to support the hypothesis that the continuous use of capsaicin can result in benefits for chagasic patients in order to decrease substance $\mathrm{P}$ and, consequently, reduce morbidity by decreasing the generalized inflammatory process. This approach is one of the perspectives for the continuation of this study. Another aspect to be discussed is the fact that substance $P$ is related to the stimulation of the production of interleukins IL1, IL6, IL8, and TNF-alfa (Adad et al. 2001), which are involved in the resistance of the parasite. Once the treatment with capsaicin is able to deplete them, other perspective for the expansion of this study would be the investigation of the effect of the treatment with capsaicin on the production of different interleukins by Swiss mice infected by T. cruzi, associated or not to different interventions.

\section{CONCLUSION}

The model of the chronic infection in Swiss male mice infected by $T$. cruzi Y strain and chronified by the discontinuous treatment with benznidazole was described 
observing the changes in the myenteric neuronal population (the decrease in the density/neuronal death and morphometric changes), as they are directly related to the inoculum and the time of infection with consequent plastic changes culminating in the hypertrophy of these neurons.

\section{ACKNOWLEDGMENTS}

This research was supported by grants from Coordenação de Aperfeiçoamento de Pessoal de Nível Superior (CAPES) and Fundação Araucária.

\section{RESUMO}

Definir um modelo experimental de avaliação de alterações quantitativas e morfométricas nos neurônios mientéricos do cólon de camundongos infectados pelo Trypanosoma cruzi. Vinte e oito camundongos Swiss machos foram distribuídos nos grupos: controle (GC, $\mathrm{n}=9)$ e infectados com $100\left(\mathrm{IG}_{100}\right.$, $\mathrm{n}=9)$ e $1000\left(\mathrm{IG}_{1000}, \mathrm{n}=10\right)$ tripomastigotas sanguíneos, cepa Y-T. cruzi II. A parasitemia foi avaliada 3-25 dias pós inoculação (dpi), com pico de parasitos de 7,7 × $10^{6}$ e $8,4 \times 10^{6}$ tripomastigotas $/ \mathrm{mL}$ no $8^{\circ}$ dpi $(\mathrm{p}>0,05)$ em $\mathrm{IG}_{100}$ e $\mathrm{IG}_{1000}$, respectivamente. A fase crônica da infecção foi obtida com duas doses de $100 \mathrm{mg} / \mathrm{Kg} /$ weight e uma dose de $250 \mathrm{mg} / \mathrm{Kg} /$ weight do benznidazol, em 11, 16 e 18 dpi. Três animais de cada grupo foram sacrificados aos 18,30 e 75 dpi. O cólon foi corado com Giemsa. A análise quantitativa e morfométrica de neurônios revelou que a infecção causou uma diminuição da densidade neuronal no $30^{\circ}$ dpi $(p<0,05)$ e 75 dpi $(p<0,05)$ em $\mathrm{IG}_{100}$ e $\mathrm{IG}_{1000}$. A infecção causou morte e hipertrofia neuronal no $75^{\circ}$ dpi em $\mathrm{IG}_{100}$ e $\mathrm{IG}_{1000}(\mathrm{p}<0,05, \mathrm{p}<0,01)$. As alterações observadas nos neurônios mientéricos foram diretamente relacionadas ao inóculo e tempo de infecção.

Palavras-chave: doença de Chagas, cólon, sistema nervoso entérico, Giemsa, Trypanosoma cruzi.

\section{REFERENCES}

Adad SJ, Cançado CG, Etchebehere RM, TeiXeira VP, Gomes UA, Chapedeiro E ANd Lopes ER. 2001. Neuron count reevaluation in the myenteric plexus of chagasic megacolon after morphometric neuron analysis. Virchows Arch 438: 254-258.

Aleixo DL, Ferraz FN, de Melo CS, Gomes ML, Toledo MJ, Kaneshima EN, Bersani-Amado CA AND DE ARAújo SM. 2008. Changes of RAPD profile of Trypanosoma cruzi II with Canova and Benznidazole. Homeopathy 97: 59-64.
Arantes RME, Marche HHF, Bahia MT, CUnha FQ, ROSSI MA AND SILVA JS. 2004. Interferon-y-induced nitric oxide causes intrinsic intestinal denervation in Trypanosoma cruzi-infected mice. Am J Pathol 164: 13611368.

Araújo SM, Andó MH, CAssarotti DJ, Mota DCGD, Borges SM AND Gomes ML. 2000. Programa ACHEI: Atenção ao Chagásico com Educação Integral no município de Maringá e região Noroeste do Paraná, Brasil. Rev Soc Bras Med Trop 33: 565-572.

ARAúJo SM AND CHIARI E. 1988. Caracterização Biológica de Clones das Cepas Y, Cl e Mr de Trypanosoma cruzi em Camundongos C3H Isogênicos. Rev Soc Bras Med Trop 83: 175-181.

BARBOSA AJA. 1978. Técnica histoquímica para gânglios nervosos intramurais e preparados espessos. Rev Bras Pes Med Biol 11: 95-97.

BRENER Z. 1962. therapeutic activity and criterion of cure on mice experimentally infected with Trypanosoma cruzi. Rev Inst Med Trop 4: 389-396.

D'Arce Mota DCG, Gomes ML and de Araújo SM. 2008. Programa achei e o princípio da autonomia: exemplo de como um serviço de saúde pode informar o usuário de maneira simples e acessível. SaBios: Rev Saúde e Biol 3: 5-9.

DE LANA M AND TAFURI WL. 2005. Trypanosoma cruzi e doença de Chagas. In: Neves DP, DE Melo AL, LINARDI PM AND VITOR RWA. Parasitologia humana. $11^{\mathrm{a}}$ ed., São Paulo: Atheneu, 85 p.

Fabbro DL, Streiger ML, Arias ED, Bizai ML, Del BARCO M AND AMICONE NA. 2007. Trypanocide treatment among adults with chronic Chagas disease living in Santa Fé City (Argentina), over a mean follow-up of 21 years: parasitological, serological and clinical evolution. Rev Soc Bras Med trop 40: 1-10.

FURNESS JB AND COSTA M. 2006. The enteric nervous system. New York: Churchill Livingstone, p. 1-28.

GRATON V. 2009. Você conhece a capsaicina? Disponível em: < http://www.nutricaosadia.com.br/2009/07/pimenta-qual-sua-importancia-para-sua.html $>$. Disponível em: 13-08-2009.

Hotez PJ, Bottazzi me, Franco-Paredes C, Ault SK And PERIAgo MR. 2008. The neglited tropical diseases of Latin America and the Caribbean: A review of disease burden and distribuition and a roadmap for control and elimination. PLoS Negl Trop Dis 2: 1-10.

IANTORNO G ET AL. 2007. The enteric nervous system in chagasic and idiopathic megacolon. AM J Surg Pathol 31: 460-468.

JANNiN J AND VilLA L. 2007. An overview of Chagas disease treatment. Mem Inst Oswaldo Cruz 102: 95-97. 
JurberG C. 2009. Chagas: one hundred years later. Bull World Health Organ 87: 491-492.

Koberle F. 1968. Chagas' disease and Chagas' syndromes: the pathology of American trypanosomiasis. Adv parasitol 6: 63-116.

Koberle F. 1970. The causation and importance of nervous lesions in American Trypanosomiasis. Bull World Health Organ Org 42: 739-743.

MAIFRINO LBM. 1996. Aspectos morfológicos, histoquímicos e imunohistoquímicos do plexo mientérico do colo de camundongo 'swiss' (Mus musculus) na fase crônica da infecção por Trypanosoma cruzi Cepa Y. São Paulo, 1996 (Tese de Doutorado - Universidade de São Paulo).

MAIFrino LBM, AMARAL SON, WATANABE I, LiBERTI EA AND Zousa RR. 2005. Trypanosoma cruzi: Preliminary investigation of NADH-positive and somastotatinimmunoreactive neurons in the myebteric plexus of the mouse colon during the infection. Exp Parasitol 111: 224-229.

MAIFrino LBM, LiberTi EA, WATANABE II-SEI AND SouzA RR. 1999. Morfhometry and acetylcholinesterase activity colon in the chronic phase of experimental Trypanosome cruzi infection. Am J Trop Med Hyg 60: 721-725.

Marin-Neto JA, Cunha-Neto E, Marcial BC And SIMÕES MV. 2007. Pathogesesis of chronic Chagas heart disease. Circulation 115: 1109-1123.

MARtins HR ET AL. 2008. Persistence of PCR-positive tissue in benznidazole-treated mice with negative blood parasitological and serological tests in dual infections with Trypanosoma cruzi stocks from different genotypes. J Antimicrob Chemother 61: 1319-1327.

Meyer IF, KANEShima EM AND DE SOUZA-KANEShima AM. 2006. Alterações no sistema digestivo desencadeadas pelo quadro infeccioso do Trypanosoma cruzi. Iniciação Científica CESUMAR 8: 11-23.
MURTA SMF AND ROMANHA AJ. 1998. In vivo selection of a population of Trypanosoma cruzi and clones resistant to benznidazole. Parasitology 116: 165-171.

Paho - Pan American Health Organization. 2007. Health in the Americas (2007) Regional, scientific and technical publication. PLoS Negl trop Dis 622: 176-182.

SANTOS JR AND Monteiro JC. 2002. Megacólon-Parte II: Doença de Chagas. Rev Bras Coloproctol 4: 266-267.

Schebeleski-SoAres C, Occhi RC, De Moraes F, Marta SD, de Oliveira M, Almeida FN, Toledo MJO AND ARAujo SM. 2009. Pre-Infection Aerobic Treadmill Training Improves Resistance against. Appl Physiol Nut Metab 34: 659-665.

SENIOR K. 2007. Chagas disease: moving towards global elimination. Lancet Infect Dis 7: 572.

Silveira ABM, D’Avila Reis D, Oliveira EC, Neto SG, Luquetti AO, Poole D, Correa-Oliveira R AND FURness JB. 2007a. Nurochemical coding of the enteric nervous system in chagasic patients with megacolon. Dig Dis Sci 52: 2877-2883.

Silveira ABM, Freitas MAR, Oliveira EC, Neto SG, Luquetti AO, Furness JB, CORREA-Oliveira R AND D'AVILA REIS D. 2008. Neuronal plasticity of the enteric nervous system is correlated with chagasic megacolon development. Parasitology 135: 1337-1342.

Silveira ABM, Lemos EM, AdAde SJ, Oliveira RC, FurNes JB AND REIS DD. 2007b. Megacolon in Chagas disease: a stury of inflammatory cells, enteric nerves, and glial cells. Hum Pathol 38: 1256-1264.

TAFURI WL, MARIA TA AND LOPES ER. 1971. Lesões do plexo mientérico do esôfago, do jejuno e do colo de chagásicos crônicos. Ver Inst Med Trop 13: 76-91.

Winter J, Bevan S And CAmpbell EA. 1995. Capsaicin and pain mechanisms. British J Anesthesia 75: 157-168. 